\title{
Chikungunya infection in a French traveller returning from the Maldives, October, 2009
}

M Receveur ${ }^{1}$, K Ezzedine (khaled.ezzedine@chu-bordeaux.fr) ${ }^{1}$, T Pistone $^{1}$, D Malvy ${ }^{1}$

1. Travel Clinics and Unit for Tropical Medicine and Imported Diseases, Department of Internal Medicine and Tropical Diseases, Hôpital St-André, University Hospital Centre, Bordeaux, France

Citation style for this article: Receveur M, Ezzedine K, Pistone T, Malvy D. Chikungunya infection in a French traveller returning from the Maldives, October, 2009. Euro Surveill. 2010;15(8):pii=19494. Available online: http://www.eurosurveillance.org/ViewArticle.aspx?Articleld=19494

This article has been published on 25 February 2010

In the last years, cases of chikungunya fever have been reported in international travellers returning from the Indian Ocean region. The cases have been linked to the re-emergence of chikungunya fever on Indian Ocean islands in 2006. We describe the first case of chikungunya fever in a French traveller returning from Malé, an island of the Maldives islands, confirming the permanence of virus circulation by the end of 2009 .

\section{Introduction}

Chikungunya virus is a mosquito-borne alphavirus found in the tropical regions of Africa and Asia where it causes endemic and epidemic chikungunya fever, an acute self-limiting febrile algo-eruptive illness [1]. Chikungunya fever has been increasingly reported in international travellers following its re-emergence on Indian Ocean islands and its spread to southern Asia thereafter [2-4]. Moreover, some African and southeast Asian countries show an endemic circulation of the virus [5] which may contribute to occurrence of the disease among travellers. The illness was suspected to have emerged in the Maldives archipelago in 2007 [6], following the sweeping succession of outbreaks that occurred in the Indian Ocean region where it first affected Kenya in 2004, Réunion Island in 2005 and southern India in $2006[1,7]$. Here we report a confirmed case of chikungunya fever in a French traveller returning from Malé island, the Maldives, where an outbreak of chikungunya fever was reported starting in January 2009.

\section{Case report}

A French male in his thirties presented at the posttravel clinic of the Department of Internal Medicine and Tropical Diseases of the University Hospital Centre, Bordeaux, France in October 2009 with symptoms of recurrent high-grade fever (up to $40^{\circ} \mathrm{C}$ ), headache, generalised muscle aches and severe joint pain mainly affecting fingers, wrists, knees and ankles, and an itching skin rash, since three days. Two days before, he had returned directly from a holiday trip to the Maldives where he had stayed for 14 days exclusively in the northern part of Malé island.
In our centre, the patient presented with a slight macular skin rash on the trunk and limbs, a slightly swollen right knee and small joints of hands and feet. Laboratory tests at the time of presentation showed a leucocyte cell count of 4,600 white blood cells (WBC)/ $\mu \mathrm{L}$, a thrombocyte count of 178,000 platelets $/ \mu \mathrm{L}$ and an elevated C-reactive protein level $(27 \mathrm{mg} / \mathrm{L}$; normal $<5 \mathrm{mg} / \mathrm{L})$. Alanine aminotransferase, aspartate aminotransferase and lactate dehydrogenase were within normal limits. Blood smears for malaria and blood cultures were negative.

Chikungunya virus serology testing was conducted for specific immunoglobulin (Ig) $G$ and $M$ using IgMcapture and IgG-sandwich enzyme-linked immunosorbent assay (ELISA) with inactivated cell-culture-ground chikungunya virus and mouse anti-chikungunya hyperimmune ascitic fluid at the National Reference Centre for Arboviruses, Institut Pasteur, Paris, France. Serology for chikungunya virus revealed positive results for both specific IgM (optic density $(O D)=1.633$; serum control $O D=0.073)$ and IgG $(O D=0.475$; serum control OD=0.096).

Paired serology for specific IgG and $M$ by ELISA against dengue virus and Japanese $B$ encephalitis were negative, as well as tests for leptospirosis, rickettsiosis, Q fever, West Nile virus and cytomegalovirus. A real-time PCR test was negative for dengue viruses and chikungunya virus RNA [8]. Fever decreased the day following the consultation, but severe joint pain persisted over six weeks until the end of December despite symptomatic treatment.

\section{Discussion}

Over the last couple of years and following successive waves of outbreaks in the Indian Ocean area since 2006, chikungunya has increasingly been reported in travellers returning from vacation in the region and in expatriates or immigrants back from visits to their home countries $[2-4,9]$.

The new case described provides definite evidence of ongoing chikungunya virus transmission in the 
Maldives. To the best of our knowledge, this case is reportedly the third confirmed chikungunya fever case imported from the Maldives since the first documented outbreak of chikungunya in Malé and other islands of the Maldives that lasted from December 2006 to April 2007 [6], followed by a suspected cluster on the Laamu Atoll from December 2008 to January 2009 [10] and the report of two confirmed cases in German travellers, a father and son returning from a 10-day visit to the Maldives mid-September 2009 [11].

The region is probably one of the most popular travel destinations in the Indian Ocean area. This may result in an increase of symptomatic travellers returning from this area and seeking medical advice at travel or primary care clinics. Hence, chikungunya together with dengue fever should be considered as an important differential diagnosis in those patients, assuming that both diseases are endemic in certain regions of India and the Indian Ocean area and may present with similar symptoms.

For more than 10 years, dengue fever was the only vector-borne viral disease reported in the Maldives. Aedes aegypti and $A$. albopictus, the dengue virus vectors which can also transmit the chikungunya virus, have been identified in the Maldives, with $A$. aegypti identified as the predominant vector in Malé [6]. The first chikungunya fever outbreak occurred from December 2006 to April 2007 with abrupt onset and high attack rates due to the lack of herd immunity. Epidemics may occur following an interval of 20-30 years of the virus not circulating as has been the case in western Africa and Malaysia [5, 6]. Confirmed imported cases among travellers support the assumption of endemic circulation of the virus which is consistent with the prevailing chikungunya epidemic in the Indian Ocean region.

This report highlights the need for surveillance in countries where emerging infections may be introduced by returning travellers as in the case with the Italian chikungunya fever epidemic which occurred in the province of Ravenna in 2007 [12]. It illustrates how travellers can serve as sentinel population providing information regarding the emergence or re-emergence of an infectious pathogen in a source region. Travellers can thus act as carriers who inadvertently ferry pathogens that can be used to map the location, dynamics and movement of pathogenic strains [9]. Thus, with the increase in intercontinental travel, travellers can provide insights into the level of the risk of transmission of infections in other geographical regions.

\section{Conclusion}

We report a case of dengue-like illness diagnosed as chikungunya in a tourist returning from the Maldives, a popular tourist spot. Despite the clinical similarity with dengue fever, chikungunya should be recognised early in returning travellers because of its specific protracted morbidity and its potential for causing local outbreaks in European countries, where local transmission is possible through the presence of the receptive vector in southern European countries.

\section{References}

1. Renault P, Solet JL, Sissoko D, Balleydier E, Larrieu S, Filleul $L$, et al. A major epidemic of chikungunya virus infection on Reunion Island, France, 2005-2006. Am J Trop Med Hyg. 2007;77(4):727-31.

2. Taubitz W, Cramer JP, Kapaun A, Pfeffer M, Drosten C, Dobler G, et al. Chikungunya fever in travellers: clinical presentation and course. Clin Infect Dis. 2007;45(1):e1-4.

3. Larrieu S, Pouderoux N, Pistone T, Filleul L, Receveur MC, Sissoko D, et al. Factors associated with persistence of arthralgia among chikungunya virus-infected travellers: report of 42 French cases. J Clin Virol. 2010;47(1):85-8.

4. Simon F, Parola P, Grandadam M, Fourcade S, Oliver M, Brouqui $P$, et al. Chikungunya infection: an emerging rheumatism among travellers returned from Indian Ocean islands. Report of 47 cases. Medicine (Baltimore). 2007;86(3):123-37.

5. AbuBakar S, Sam IC, Wong PF, MatRahim N, Hooi PS, Roslan N. Reemergence of endemic Chikungunya, Malaysia. Emerg Infect Dis. 2007;13(1):147-9.

6. Yoosuf AA, Shiham I, Mohamed AJ, Ali G, Luna IM, Pandav R, et al. First report of chikungunya from the Maldives. Trans R Soc Trop Med Hyg. 2009;103(2):192-6.

7. Sissoko D, Malvy D, Ezzedine K, Renault P, Moscetti F, Ledrans M, et al. Post-epidemic Chikungunya disease on Reunion Island: course of rheumatic manifestations and associated factors over a 15-month period. PLoS Negl Trop Dis. 2009;3(3):e389.

8. Pastorino B, Bessaud M, Grandadam M, Murri S, Tolou $\mathrm{H}$, Peyrefitte CN. Development of a TaqMan RT-PCR assay without RNA extraction step for the detection and quantification of African Chikungunya viruses. J Virol Methods. 2005;124(1-2):65-71.

9. Pistone T, Ezzedine K, Schuffenecker I, Receveur MC, Malvy D. An imported case of Chikungunya fever from Madagascar: use of the sentinel traveller for detecting emerging arboviral infections in tropical and European countries. Travel Med Infect Dis. 2009;7(1):52-4

10. Acute febrile disease - Maldives: (Laamu Atoll). In: ProMEDmail [online]. Boston US: International Society for Infectious Diseases; 14 January 2009. Archive no. 20090114.0150. Available from: http://www.promedmail.org

11. Chikungunya (34): Germany ex Maldives. In: ProMED-mail [online]. Boston US: International Society for Infectious Diseases; 22 September 2009. Archive no. 200900922.3337. Available from: http://www.promedmail.org

12. Angelini R, Farinelli AC, Angelini P, Po C, Petropulacos K, Macini $P$, et al. An outbreak of chikungunya fever in the province of Ravenna, Italy. Euro Surveill. 2007;12(36):pii=3260. Available from: http://www.eurosurveillance.org/ViewArticle. aspx?Articleld $=3260$ 